\title{
Social Competence and Obesity in Teenagers: An Analysis of the Last Ten Years of Studies
}

\author{
Graziela Sapienza1, Teresa Helena Schoen², Mauro Fisberg² \\ ${ }^{1}$ Department of Psychology, Pontifical Catholic University of Parana, Curitiba, Brazil \\ ${ }^{2}$ Department of Pediatric, Federal University of São Paulo, São Paulo, Brazil \\ Email: graziela_sapienza@yahoo.com.br
}

How to cite this paper: Sapienza, G. Schoen, T.H. and Fisberg, M. (2017) Social Competence and Obesity in Teenagers: An Analysis of the Last Ten Years of Studies. Health, 9, 1618-1631.

https://doi.org/10.4236/health.2017.912119

Received: September 1, 2017

Accepted: November 10, 2017

Published: November 13, 2017

Copyright ( 92017 by authors and Scientific Research Publishing Inc. This work is licensed under the Creative Commons Attribution International License (CC BY 4.0).

http://creativecommons.org/licenses/by/4.0/

(c) (i) Open Access

\begin{abstract}
Socially competent people using better strategies for solving interpersonal problems are more readily accepted by peers and valued by adults. Obese individuals, especially teenagers, have deficits in several social skills, which lead to damage to the relationships, self-esteem and in their valuation by social agents. This study examines how the literature of the last decade associates the components of social competence to obesity in adolescents. The research was carried out in electronic databases in the period between Jan. 2005 and Dec. 2015, resulting in 329 articles. 303 were excluded as they did not meet the inclusion criteria, and 26 original articles have been analyzed. The results showed that the components of social competence were negatively associated with obesity and most studies focused on self-esteem, pattern of interaction with peers and social relationship. The social competence was highlighted as important for interventions aimed at reducing weight.
\end{abstract}

\section{Keywords}

Obesity, Adolescence, Social Competence, Social Skills, Prevention

\section{Introduction}

Obesity is one of the most difficult chronic diseases to treat, especially in adolescents. Many factors contribute negatively, such as the low-involvement of the family, the low self-esteem and poor self-control that make it difficult to adhere to the medical advice and nutrition. The lack of psychological support and the non-association of the physical activity with the nutritional guidance, also produce negative results to the treatment [1].

On the other hand, social competence may function as a protection factor that contributes to reducing the consequences of obesity [2] [3]. Socially competent 
individuals behave in a way that promotes health, life quality and generates happiness, which encourages the inclusion of actions that develop these competences in prevention programs.

Social competence is the ability of the individual to direct behavior to achieve their goals in social interactions, considering the demands of the situation and the culture, bringing positive results for the individual and for their relationships with the other social agents [4] [5]. The concept of social competence includes social skills, the skills of self-assessment of the social performance (self-esteem, self-concept, self-efficacy), the enhancement of their social performance performed by social agents (parents, teachers) and the pattern of relationships with peers (acceptance and rejection).

Obese adolescents show deficits in social competence involving mainly the social skills, relationships with peers and self-valuation skills. It is common that they are not able to control their feeding impulses, mainly in situations of interaction with peers and, girls especially, have difficulties in resisting when a friend offers something to eat or when they show problems such as social anxiety, anger, frustration or sadness. The obese often feel rejected by peers or perceive themselves as victims of nicknames, prejudices or offensive jokes from their peers [6]. Difficulties in the relationships with peers affect the self-esteem, leading to psychological suffering and the avoidance of routine activities and social interaction, such as going to school, practicing some sports, having fun, buying clothes and dating [3]. These restrictions are hampering the acquisition of social reinforcement and the enhancement of important social behaviors for this age group [7].

Among the abilities of self-valuation, self-esteem and lowered self-concept are often associated with obesity. Obese individuals tend to feel less satisfied with their physical appearance and their performance in social activities, such as sports and participation in groups [8] [9] [10]. To compensate for their low self-esteem [11], the obese adolescent uses the pleasure that the food provides, contributing to the maintenance and the worsening of the problem.

Knowing that being socially responsible is a relevant factor for the choice of healthy lifestyle and for the well-being and happiness of the individual, this review investigates how the literature of the last decade associates social competence to treatments of adolescent obesity, indicating the most researched components of social competence, the instruments used to measure this construct, who are the social agents involved in the assessments or interventions to improve these skills and what are the main relationships between social competence and obesity.

\section{Material and Methods}

Databases and search strategies: BVS (Biblioteca Virtual de Saúde), PsycINFO, SciELO, Pubmed e ISI Web of Science, in Jan 2016. The descriptors used in the searches were: obesity, adolescence, adolescents, social competence, social skills, 
in Portuguese and English. These terms could appear in any field of their databases. The period of publication was from Jan. 2005 to Dec. 2015 and full-text articles, independent of language, were selected.

\subsection{Inclusion Criteria}

To answer the question "How the components of social competence are associated with obesity in adolescence?", the complete articles that met the two criteria were included in this review: 1) the investigated population should include adolescents from 10 to 19 years [12], even containing individuals of other age groups, 2) the authors should involve aspects of social competence to the treatment of obesity, and 3) the manuscripts must be with full text.

\subsection{Exclusion Criteria}

The material in the form of editorials, letters, dissertations not published under format of scientific article, review articles, in addition to studies involving pregnant adolescents, patients with any disease or psychiatric disorder or that were related to any medical procedure, were excluded from the analysis. However, articles relating to disorders or psychological problems often associated with deficits of social competence, such as low self-esteem and depression, were kept for analysis.

\subsection{Data Extraction}

The selection of studies and the extraction of information were made by two researchers, independently, completing a single form, designed for this paper. The selected articles were arranged in ascending order according to the year of publication and formed a list containing also authors, journal published and the country where the study was conducted. The recovered materials were separated for the data extraction and analysis and classified in observational or interventional studies [13]. Observational studies were considered as those that some instrument was applied to identify the components of social competence in obese adolescent. For an article to be classified as an interventional study, it was necessary that obese adolescents participated in some type of intervention for weight control, involving actions with the adolescents themselves (direct intervention) or with social agents (indirect intervention) related to them (parents, teachers or peers). The data extracted from the observational studies were: participants' characteristics (age and sex), sample size (N), parameters used for definition of excess weight and obesity, identified components of social competence, measurements of social competence and main relationships between social competence and obesity. In addition to these data, from interventional studies, actions for development of social competence were identified.

\section{Results}

Initially 329 papers were recovered. After the reading of the titles and abstracts, 
281 articles were excluded because they did not identify aspects of social competence in these fields, because they did not include individuals in the age group chosen, or by having been recovered in duplicate by different databases. 48 articles remained for analysis. To extract the data the complete manuscript was sought and proceeded to reading. This more comprehensive examination led to the exclusion of 22 more articles because they did not meet the inclusion criteria, which left 26 articles for analysis.

The data collection period of the analyzed studies was from Jan. 2005 to Dec. 2015, with there being more studies with the data collected over the past 05 years $(n=18)$. The studies, in their majority $(n=23)$, were conducted in developed countries, mainly in the United States $(n=14)$. Among developing countries, Brazil was the only one which appeared with 3 articles among the selected studies.

The results analyzed come from observational studies $(n=13)$ that had as a source of data especially surveys with representativeness of segments of the population and of interventional studies $(n=13)$ that compared or tested the effectiveness of some kind of treatment. This characteristic is reflected, in part, in the large variation observed in the number of participants of the studies: of 54.863 adolescents assessed in a study that showed associations between the use of media and health with children in the United States, to 2 (two) adolescents who experienced behavioral intervention conducted in Brazil and presented as a case study. The average age of the participants ranged from 9.5 years $(n=1)$ a $16.5(n$ $=1)$.

The parameter used to define overweight and obesity in adolescents included as participants of the studies analyzed was the Body Mass Index (BMI), accepting that the percentiles BMI > 85 (overweight) and BMI > 95 (obesity), based on the curves of the Center for Disease Control and Prevention/National Center for Health Statistic - CDC/NCHS [14]. The BMI could be calculated using the weight and height measured or reported by parents or by the adolescents. Only in two interventional studies [15] [16] is it not clear if any parameter was used to define overweight and obesity.

Table 1 shows the characteristics of the individuals studied ( $N$, age and sex), the classification of study, the identified components of social competence and the instruments of measurements of social competence.

Data on the agents involved in the interventions, types of intervention identified for development of social competence and the main relationships between social competence and obesity are described below.

All interventions were performed directly with the adolescents. In addition, the family members, especially parents, participated in 05 interventions [31] [33] [34]. Two studies involved colleagues, examining the influence of peer support for weight loss [37] [38]. The adolescents' teachers were involved in only one intervention among the studies analyzed [15].

The selected studies had obesity as their main target, but could include as an 
Table 1. Data extracted from selected studies.

\begin{tabular}{|c|c|c|c|c|c|}
\hline ID & $\begin{array}{c}\text { Study } \\
\text { (author, year) }\end{array}$ & $\begin{array}{c}\text { Participants } \\
\text { (N, age, gender) }\end{array}$ & Study design & $\begin{array}{l}\text { Components of social } \\
\text { competence }\end{array}$ & Measurements of social competence \\
\hline 1 & Cortese et al., 2005 [17] & $\begin{array}{l}\quad \begin{array}{l}\mathrm{N}=56 \\
9-16\end{array} \\
\text { Boys and girls }\end{array}$ & Observational & Self-esteem & $\begin{array}{l}\text { Multidimensional Self Concept } \\
\text { Scale-MSCS }\end{array}$ \\
\hline 2 & $\begin{array}{l}\text { Riggs, Sakuma and Pentz, } \\
2007[15]\end{array}$ & $\begin{array}{l}\quad \mathrm{N}=200 \\
11 \\
\text { Boys and girls }\end{array}$ & Interventional & Self-control & Questionnaire developed by the authors \\
\hline 3 & $\begin{array}{l}\text { Stein, Fisher, Berkey and } \\
\quad \text { Colditz, } 2007 \text { [18] }\end{array}$ & $\begin{array}{l}\mathrm{N}=8670 \\
\quad 9-14 \\
\text { Boys and girls }\end{array}$ & Observational & Self-perception & $\begin{array}{l}\text { Harter Self-Perception } \\
\text { Profile for Children (Harter, 1985) } \\
\text { —adapted version }\end{array}$ \\
\hline 4 & $\begin{array}{l}\text { Eriksson, Nordqvist and } \\
\text { Rasmussen, } 2008 \text { [19] }\end{array}$ & $\begin{array}{c}\quad \mathrm{N}=1124 \\
\quad 12 \\
\text { Boys and girls }\end{array}$ & Observational & $\begin{array}{l}\text { Self-esteem } \\
\text { Self-perception }\end{array}$ & $\begin{array}{l}\text { Harter's Self-Perception Profile for } \\
\text { Adolescents (Harter, 1988) }\end{array}$ \\
\hline 5 & $\begin{array}{l}\text { Zeller, Reiter-Purtill and } \\
\text { Ramey, } 2008 \text { [20] }\end{array}$ & $\begin{array}{l}\quad \begin{array}{l}\mathrm{N}=166 \\
\quad 8-16\end{array} \\
\text { Boys and girls }\end{array}$ & Observational & $\begin{array}{l}\text { Adult appreciation } \\
\quad \text { (teachers) } \\
\text { Self-valuation } \\
\text { Peers-perception }\end{array}$ & $\begin{array}{l}\text { Child's peer acceptance (Asher, } \\
\text { Singleton, Tinsley and Hymel, 1979) } \\
\text { Revised Class Play_-RCP (Masten, } \\
\text { Morison and Pellegrini, 1985) }\end{array}$ \\
\hline 6 & $\begin{array}{l}\text { Martyn-Nemeth, Penckofer, } \\
\text { Gulanick, Velsor-Friedrich } \\
\text { and Bryant, } 2009[21]\end{array}$ & $\begin{array}{c}\mathrm{N}=102 \\
14-18 \\
\text { Boys and girls }\end{array}$ & Observational & Self-esteem & $\begin{array}{l}\text { Rosenberg Self-Esteem short-form } \\
\text { (Rosenberg, 1965) } \\
\text { Coping Across Situations Questionnaire } \\
\text {-CASQ } \\
\text { (Seiffge-Krenke, 1995) }\end{array}$ \\
\hline 7 & $\begin{array}{l}\text { Russ, Larson, Franke and } \\
\text { Halfon, } 2009 \text { [22] }\end{array}$ & $\begin{array}{l}\mathrm{N}=54,863 \\
\quad 6-17 \\
\text { Boys and girls }\end{array}$ & Observational & Social functioning & Questions made for this study \\
\hline 8 & $\begin{array}{l}\text { Luiz, Gorayeb, Liberatore Jr } \\
\text { and Domingos, } 2010 \text { [3] }\end{array}$ & $\begin{array}{l}\quad \begin{array}{l}\mathrm{N}=90 \\
7-13\end{array} \\
\text { Boys and girls }\end{array}$ & Observational & Social competence & $\begin{array}{l}\text { Child Behavior Checklist-CBCL } \\
\text { (Achenbach and Edelbrock, 1991) }\end{array}$ \\
\hline 9 & Lumeng et al., 2010 [23] & $\begin{array}{l}\quad \mathrm{N}=821 \\
\quad 8-11 \\
\text { Boys and girls }\end{array}$ & Observational & $\begin{array}{l}\text { Social skills } \\
\text { (assertiveness, } \\
\text { empathy and } \\
\text { self-control) }\end{array}$ & $\begin{array}{l}\text { Social Skills Rating System-SSRS } \\
\text { (Gresham and Elliott, 1990) }\end{array}$ \\
\hline 10 & $\begin{array}{c}\text { Meyer and Barbosa, } 2010 \\
{[24]}\end{array}$ & $\begin{array}{c}\quad \mathrm{N}=2 \\
13-16 \\
\text { Boys and girls }\end{array}$ & Interventional & $\begin{array}{l}\text { Assertiveness } \\
\text { Isolation }\end{array}$ & Data record for functional analysis \\
\hline 11 & $\begin{array}{c}\text { Schoen-Ferreira, Sayegh, } \\
\text { Damaso and Cintra., } 2010 \\
{[6]}\end{array}$ & $\begin{array}{c}\mathrm{N}=160 \\
14-19 \\
\text { Boys and girls }\end{array}$ & Observational & $\begin{array}{l}\text { Social relationship } \\
\text { Peers interaction }\end{array}$ & $\begin{array}{l}\text { The Friendship Questionnaire-FQ } \\
\text { (Baron-Cohen and Wheelwright, 2003, } \\
\text { Pedromônico, Marteleto and } \\
\text { Schoen-Ferreira, 2004) }\end{array}$ \\
\hline 12 & $\begin{array}{l}\text { Tsukayama, Toomey, Faith } \\
\text { and Duckworth, } 2010 \text { [25] }\end{array}$ & $\begin{array}{c}\mathrm{N}=844 \\
15 \\
\text { Boys and girls }\end{array}$ & Observational & Social skills & SSRS (Gresham and Elliott, 1990) \\
\hline 13 & $\begin{array}{l}\text { de Niet, Timman, Jongejan, } \\
\text { Passchier and van den } \\
\text { Akker, } 2011[26]\end{array}$ & $\begin{array}{c}\mathrm{N}=248 \\
\quad 8-14 \\
\text { Boys and girls }\end{array}$ & Interventional & Social Competence & $\begin{array}{l}\text { CBCL (Achenbach and Edelbrock, } \\
1991 \text { ) }\end{array}$ \\
\hline 14 & de Niet et al., 2011 [27] & $\begin{array}{c}\quad \mathrm{N}=248 \\
\quad 8-14 \\
\text { Boys and girls }\end{array}$ & Interventional & Social Competence & $\begin{array}{l}\text { CBCL (Achenbach and Edelbrock, } \\
1991 \text { ) }\end{array}$ \\
\hline
\end{tabular}




\section{Continued}

15

ackson, von Eye, Fitzgerald, Witt and Zhao, 2011 [28]

Jacobson and Melnyk, 2011

Rehkopf, Laraia, Segal,

17 Braithwaite and Epel, 2011 [30]

Vos, Wit, Pijl, Kruyff, and Houdijk, 2011 [31]

Walpole, Dettmer,

19 Morrongiello, McCrindle and Hamilton, 2011 [32]

Gunnarsdottir, Njardvik,

20 andBjarnason, 2012 [33]

Jacobson and Melnyk, 2012 [34]

22

Laberge, Bush and Chagnon, 2012 [16]

Walpole, Dettmer,

23 Morrongiello, McCrindle and Hamilton, 2013 [35]

Powell-Young, Zabaleta,

24 Velasco-Gonzalez and Sothern, 2013 [36]

$25 \quad$ Kulik et al., 2014 [37]

$26 \quad$ Kulik et al., 2015 [38]

$$
\mathrm{N}=482
$$

12, 19 (age average) Boys and girls

$$
\mathrm{N}=17
$$

$9-12$

Boys and girls

$N=2150$
$9-19$
Girls

$$
\mathrm{N}=80
$$

$8-17$

Boys and girls

$$
\begin{gathered}
\mathrm{N}=\# \\
10-18
\end{gathered}
$$

Boys and girls

$\mathrm{N}=84$

$7-14$

Boys and girls

$$
\mathrm{N}=17
$$

$9-12$

Boys and girls

$$
\mathrm{N}=223
$$

$11-16$ Boys and girls

$$
\mathrm{N}=40
$$

$10-18$

Boys and girls

$\mathrm{N}=264$

$14-18$

Gils

$\mathrm{N}=36$

$13-17$

Girls

$\mathrm{N}=41$

$13-17$

Girls
Interventional

Observational Self-esteem

Self-control

Social skills

Self-concept

Self-esteem

Self-control

Social Competence Social

Functioning

Self-perception Self-concept

Self-concept

Social skills

Peers interaction

Self-control

Social skills

Self-concept

Self-esteem

Peers interaction

Self-control Social skills Self-concept

Self-esteem Self-control Social competence

Self-efficacy

Interventional

Observational

Self-esteem

Interventional

Interventional
Harter's Self-Competence Scale (Harter, 1982)

Rosenberg's self-esteem scale (Rosenberg, 1989)

SSRS (Gresham and Elliott, 1990)

PCSC (Harter, 1985)

CBCL (Achenbach and Edelbrock, 1991) Youth Self-Report-YSR (Achenbach and Edelbrock, 1991)

Teacher Report Form-TRF

(Achenbach and Edelbrock, 1991)

Competence Scale for Children'-CBSK

(Veerman et al., 2007)

Rosenberg Self-Esteem Scale (Rosenberg, 1965)

Piers-Harris Self Concept Scale (Piers, 1984)

SSRS (Gresham and Elliott, 1990)

The Strengths and Difficulties Questionnaire-SDQ (Steingrimsson and Magnusson, 2008)

SSRS (Gresham and Elliott, 1990)

Conners-Wells' Adolescent Self Report Scale-C-W ASRS (Conners et al., 1997) - adapted version

Rosenberg global self-esteem scale (Rosenberg, 1965)

CDSS (Parcel et al., 1995) Weight Efficacy Lifestyle questionnaire (WEL, Clark, Abrams, Niaura, Eaton and Rossi, 1991)

Harter's Self-Perception Profile for Adolescents [SPPA] (Harter, 1988)

Social Support and Eating Habits-SSEH and Social Support and Exercise-SSE (Sallis, Grossman, Pinski, Patterson and Nader, 1987).

SSEH and SSE (Sallis, Grossman, Pinski, Patterson, and Nader, 1987).

\#. insufficient information. 
objective of the development intervention of some component of social competence, associating these two objectives $(n=9)$. Among the interventions aimed specifically for social competence in obese, 08 based their actions more on cognitive-behavioral therapy [26] [29] [32] [37] [38] even though some of them would also use other theories or techniques (social skills training, motivational interview or health programs that included techniques for interpersonal improvement). One article indicated intervention based on behavioral therapy [24]. Riggs, Sakuma and Pentz [15] do not specify that psychological approach is based on the interventions aimed at social competence. Only Laberge, Bush and Chagnon [16] did not included in article actions for development of social competence.

\section{Relationships between the Components of Social Competence and Obesity}

The main relationships between social competence and obesity were grouped to facilitate the understanding and are presented below.

Interaction with peers and obesity $(n=5)$. Obese adolescents showed a pattern in more negative interaction with peers than non-obese adolescents. They are also more often victims of bullying [6] [20] [23], but the obesity does not affect the degree of intimacy with peers [6]. Perception of peer support is important for the adolescent obese, but did not increase weight loss during the short term can [37] [38].

Social skills and obesity $(n=5)$. Deficits in self-control were associated with increased weight and obesity [15] [25] [29] [34], because they interfere with the healthy lifestyle choices.

Self-valuation skills and obesity $(\mathrm{n}=4)$. Obese adolescents have lowered self-esteem in relation to non-obese adolescents [36]. The higher the weight, the lower the level of self-concept [29] or self-efficacy [35]. Cortese et al. [17] found a different result: obese adolescents do not have lower self-esteem than the rest of the population.

Social relationship and obesity $(n=3)$. Obese adolescents present loss in social functioning and social acceptance [20]. Teachers perceive the obese adolescents as more willing to help colleagues [20]. Difficulties in social relationship lead to the withdrawal of treatment [26]. Positive perception of peer support influences treatment [39].

Social Competence and obesity $(n=3)$. The social competence should be the target of interventions against obesity [31] since its development is inversely proportional to the weight gain [24] [27].

Use of media, social competence and obesity $(n=3)$. The more hours the obese adolescent spends in front of the television the worse their level of social competence [22]. The use of videogames was negatively related to social self-esteem [28]. The more obese people use the mobile phone, the higher their level of social competence (self-esteem) [29]. 
Sedentary lifestyle, social competence and obesity $(n=2)$. Adolescents above the weight that increase the frequency of physical activity also increase the level of social competence for self-perception and self-esteem [16] [18]. In spite of this, Laberge, Bush and Chagnon [16] found that obese adolescents that have increased the frequency of physical activity had no significant difference in social competence in general or in self-control.

\section{Discussion}

Previous studies have indicated relationships between components of social competence and obesity, since, using these search terms were recovered initially more than 300 papers. However, in spite of having been recovered as work with adolescents, the majority studied aspects of social competence only in obese children, which resulted in the exclusion of many studies in this analysis. One of the inclusion criteria for the selection of studies for paper was age, which should vary from 10 to 19 years, age range classified as adolescence by the World Health Organization [39]. The studies could include participants from other ages, which caused great variation in the age of the participants of the studies analyzed here, from 9.5 to 16.5 years.

Many articles excluded due to age showed that, in the last decade there had been more emphasis in identifying psychological factors associated with obesity in children than in adolescents. The majority of studies in the literature report the influence of the first years of life, and it is precisely in this phase of higher difficulty in social and family relationship, of body and emotional changes that modify the social competence, that is the adolescence, there is a big emptiness and numerous questions, that explain the importance of this study.

This revision intends to analyze some data from studies that associate social competence and obesity in adolescents. The results showed that the majority of studies included boys and girls, indicating that the professionals are concerned with obesity in both gender and both have problems with obesity. The parameters for the definition of obesity did not vary in the studies, the BMI percentile being the most accepted.

One of the components of social competence more referred to in the studies analyzed was self-esteem $(n=9)$. Researches show the importance of this concept for the treatment of obesity, indicating that obese individuals have low levels of self-esteem [9] [21]. These levels may be associated with social acceptance, athletic competence, physical appearance, social self-esteem or global self-esteem. These variations demonstrate that the concept of self-esteem, despite the fact that, for this paper is understood as a general and unified concept, it can be understood and analyzed under various aspects, but always being considered as a feeling resulting from the self-assessment and related to self-concept, along with a sense of self-efficacy (belief in results) and the self-perception. The instruments developed by Harter (1982, 1985 and 1988) are among the most commonly used to check the self-esteem, probably because they 
are able to evaluate the different aspects of this concept, as well as to investigate the self-concept and self-perception.

The selected articles showed that obese adolescents perceive a more negative pattern of interaction with peers, frequently being considered as victims of bullying [23] and less chosen as best friends than their colleagues at healthy body weight [20]. Other studies have also observed this pattern, as Schoen-Ferreira, Sayegh, Damaso and Cintra [6] and Jackson and Cunningham [40], who found that obese young people state that they are the principle source of mockery or offensive jokes on the part of their colleagues.

It seems that patterns of rejection or isolation are common among these adolescents and that it affects learning and developing of social behavior important for social relationships as a whole [7]. In adolescence especially, in which the peer group plays an important role in the development, a positive interaction with peers is very important. One of the selected studies [17] researched the usefulness of adding the social skills training with peers to the traditional cognitive-behavioral therapy, one of the most used types of intervention in the treatment of obese patients. The authors found that, including the peers in the intervention, the results were more positive: the obese adolescents have increased the indices evaluated, especially their self-esteem in relation to physical appearance, and reduced weight after 6 months of treatment.

The quality of social relationships is among the most relevant components for the understanding or treatment of obesity, being cited in seven studies. When rejected or if isolating themselves, obese adolescents tend to exhibit problems in social relationship [3] [6]. These problems, in addition to depriving these youngsters of typical activities for their age (9 or 10) may harm their personal and professional success [4]. Problems in these areas may also be responsible for withdrawal of treatment for obesity, as indicated in one of the selected papers [26].

It is worth pointing out that not all overweight adolescents are perceived negatively and that not all aspects of social networking are harmed. In the research of Zeller, Reiter-Purtill and Ramey [20], despite non-obese peers and the adolescents depicting themselves negatively (more isolated, physically less attractive, more tired, more sick), the teachers relate that obese individuals have more pro-social behavior than their eutrophic colleagues, revealing that they are willing to help more often. Obesity also does not affect the degree of intimacy on friendships of obese adolescents [6] which, as well as their eutrophic colleagues, invest in contacting peers. Both groups considered important: the eye contact, going out with friends, visiting them and sharing feelings and secrets.

Among the social abilities, it seems that self-control is the one most damaged, when it comes to obesity. Deficits in self-control were associated with obesity in eight studies. Low levels of self-control interfere with healthy lifestyle choices (choice of foods and physical activity), the use of strategies to coping with stress and the increase of weight and BMI. On the other hand, adolescents with higher 
level of self-control have increased cooperation, in empathetic behavior, in practice of physical activities, reflecting better skill levels of self-valuation and social competence. Several studies have indicated that the enhancement of skills of self-control must be included in the treatment of obesity [31] [33] [34], which contribute to embracing medical and nutrition advice.

In addition to the identified components separately, the social skills and, more broadly, the social competence were considered by the studies selected as important to understanding and mainly to the treatment of obesity. For these studies, the greater the social competence, the lower the BMI [24] [27]. Two studies have found that adolescents who have increased the frequency of physical activity also increased the level of social competence and reduced the BMI [16] [18] showing that actions directed to these aspects are useful together. The use of media was also associated with social competence and obesity: the more time the obese adolescents spend in front of the TV, the worse their level of social competence [22]. The more hours the young obese spend playing videogames the worse their level of social competence [28]. On the contrary, the more time the obese uses the mobile phone, the higher their level of social competence [29]. However, the growing expansion of mobile devices with mobility and access to the internet (smartphones) leaves a big question mark: is the cell phone being used as a source of social integration, with the use of social networks, for the use of electronic games or as a tool of communication? It is, therefore, a tool that allows both the isolation and the possibility of further contacts. Questions pertaining to this use should be placed in the questionnaires for research.

It is necessary to point out that the social competence is a basic skill for the proper functioning in adulthood and that the individual is considered socially competent when their behavior is assessed by social agents (peers, parents and teachers) as adaptive for their age group. This skill is required in the acquisition of social reinforcements, since the children who do not have appropriate social behavior are often isolated and rejected, and may present psychological problems [6]. It seems that this idea is considered by literature, since part of the work involved parents or guardians in the gathering of data on the behavior of the obese adolescent or even in interventions. Teachers were also involved in the collection of data on aspects of the behavior of the obese student, although with a small representation, only in one of the studies analyzed.

\section{Conclusions}

The findings of this review represent part of the literature that associates social competence and obesity. The inclusion and exclusion criteria may have left out studies with important representativeness. Even so, the data that was found brought important contributions to the understanding of the mechanisms of adaptation and intervention in obese adolescents.

One of the goals of this study was to analyze how components of social competence are associated with obesity adolescents, indicating the most cited com- 
ponents, the instruments used to measure the social competence, the agents involved in the interventions and some differences in characteristics of the participants (age and sex). It is believed that it is important to compare the data here identified with studies conducted with overweight children and adults, in addition to analyzing the potential mediator or predictor of each component of the social competence in obesity. This would help to identify potential protective factors and to develop effective strategies for resilience against negative psychological aspects associated with the increase of weight.

This review considered varied components of social competence identified in obese adolescents. The understanding of this relationship helps to establish a broader focus for the work with excess weight and obesity in this age group that often involves only physical activity and guidance for feeding. The obesity in adolescents compromises the mechanisms of relationship, generation of networks of support, by isolating the individual and aggravating the negative self-image, especially at this stage of transition. In addition to this, it generates risks of bullying, altering even more the capacity of reaction and hindering the intervention. The social competence, as a psychological factor, must be considered, as it may increase or strengthen the results of nutritional interventions and physical activity for weight reduction.

\section{References}

[1] Fisberg, M. (2005) Atualização em obesidade na infância e adolescência. [Update on Obesity in Childhood and Adolescence.] Atheneu, São Paulo.

[2] Murta, S.G. (2005) Aplicações do Treinamento em Habilidades Sociais: Análise da Produção Nacional. [Applications of Training in Social Skills: Analysis of National Production.] Psicologia: Reflexão e Crítica, 18, 283-291. https://doi.org/10.1590/S0102-79722005000200017

[3] Luiz, A.M., Gorayeb, R., Liberatore Jr, R.D. and Domingos, N.A. (2010) Avaliação da depressão, problemas de comportamento e competência social em crianças obesas. [Evaluation of Depression, Behavioral Problems and Social Competence in Obese Children.] Estudos de Psicologia, 27, 41-48. https://doi.org/10.1590/S0103-166X2010000100005

[4] Del Prette, A. and Del Prette, Z.A.P. (2008) Psicologia das relações interpessoais: vivências para o trabalho em grupo. [Psychology of Interpersonal Relations: Experiences for Group Work.] Vozes, Petrópolis.

[5] Trianes, M.V., Muñoz, A.M. and Jiménez, M. (1997) Competencia social: su educación y tratamiento. [Social Competence: Education and Treatment.] Ediciones Pirámide, Madrid.

[6] Schoen-Ferreira, T.H., Sayegh, F., Damaso, A. and Cintra, I.P. (2010) Friendship among Obese and Eutrofic Adolescents. Psicologia em Revista, 16, 47-63.

[7] Falcone, E. (2000) Habilidades sociais: para além da assertividade. [Social Skills: beyond Assertiveness.] In: Wielenska, R.C., Org.,Sobre comportamento e cognição, Esetec, Santo André.

[8] Simões, D. and Meneses, R.F. (2007) Auto-Conceito em Crianças Com e Sem Obesidade. [Self-Concept in Obese and Obese Children.] Psicologia: Reflexão e Crítica, 20, 246-251. https://doi.org/10.1590/S0102-79722007000200010 
[9] McCullough, N., Muldoon, O. and Dempster, M. (2009) Self-Perception in Overweight and Obese Children: A Cross-Sectional Study. Child: Care, Health and Development, 35, 357-364. https://doi.org/10.1111/j.1365-2214.2008.00924.x

[10] Israel, A.C. and Ivanova, M.Y. (2002) Global and Dimensional Self-Esteem in Preadolescent and Early Adolescent Children Who Are Overweight: Age and Gender Differences. International Journal of Eat Disorder, 31, 424-429. https://doi.org/10.1002/eat.10048

[11] Braga, P.D., Molina, M.C.B. and Cade, N.V. (2007) Expectativas de adolescentes em relação a mudanças no perfil nutricional. [Expectations of Adolescents regarding Changes in Nutritional Profile.] Revista Ciência \& Saúde Coletiva, 12, 1221-1228. https://doi.org/10.1590/S1413-81232007000500019

[12] WHO, World Health Organization (1986) Young People's Health-A Challenge for Society. Report of a WHO Study Group on Young People and Health for All. Technical Report Series 731. WHO, Geneva.

[13] Hochman, B., Nahas, F.X., Oliveira, R.S. and Ferreira, L.M. (2005) Research Designs. Acta Cirúrgica Brasileira, 20, 2-9. https://doi.org/10.1590/S0102-86502005000800002

[14] CDC, Centers for Disease Control and Prevention (2007) Department of Health and Human Services USA. About BMI for Children and Teens. Atlanta: Centers for Disease Control and Prevention. http://www.cdc.gov/nccdphp/dnpa/bmi/childrens_BMI/about_childrens_BMI.htm

[15] Riggs, N.R., Sakuma, K.L. and Pentz, M.A. (2007) Preventing Risk for Obesity by Promoting Self-Regulation and Decision-Making Skills: Pilot Results from the PATHWAYS to Health Program (PATHWAYS). Evaluation Review, 31, 287-310. https://doi.org/10.1177/0193841X06297243

[16] Laberge, S., Bush, P.L. and Chagnon, M. (2012) Effects of a Culturally Tailored Physical Activity Promotion Program on Selected Self-Regulation Skills and Attitudes in Adolescents of an Underserved, Multiethnic Milieu. American Journal of Health Promotion, 26, 105-115. https://doi.org/10.4278/ajhp.090625-QUAN-202

[17] Cortese, S., Cuzzolaro, M., Maffeis, C., Piccolo, F., Ferrucci, G., Tatò, L., Pajno-Ferrara, F. and Dalla Bernardina, B. (2005) Depressive Symptoms and Low Self-Esteem in Obese Children and Adolescents. Minerva Pediatric, 57, 65-71.

[18] Stein, C., Fisher, L., Berkey, C. and Colditz, G. (2007) Adolescent Physical Activity and Perceived Competence: Does Change in Activity Level Impact Self-Perception? Journal of Adolescent Health, 40, 462e1-462e8.

[19] Eriksson, M., Nordqvist, T. and Rasmussen, F. (2008) Associations between Parents' and 12-Year-Old Children's Sport and Vigorous Activity: The Role of Self-Esteem and Athletic Competence. Journal of Physical Activity \& Health, 5, 359-373. https://doi.org/10.1123/jpah.5.3.359

[20] Zeller, M.H., Reiter-Purtill, J. and Ramey, C. (2008) Negative Peer Perceptions of Obese Children in the Classroom Environment. Obesity, 16, 755-762.

https://doi.org/10.1038/oby.2008.4

[21] Martyn-Nemeth, P., Penckofer, S., Gulanick, M., Velsor-Friedrich, B. and Bryant, F.B. (2009) The Relationships among Self-Esteem, Stress, Coping, Eating Behavior, and Depressive Mood in Adolescents. Research in Nursing \& Health, 32, 96-109. https://doi.org/10.1002/nur.20304

[22] Russ, S.A., Larson, K., Franke, T.M. and Halfon, N. (2009) Associations between Media Use and Health in US Children. Academic Pediatrics, 9, 300-306. https://doi.org/10.1016/j.acap.2009.04.006 
[23] Lumeng, J.C., Forrest, P., Appugliese, D.P., Kaciroti, N., Corwyn, R.F. and Bradley, R.H. (2010) Weight Status as a Predictor of Being Bullied in Third through Sixth Grades. Pediatrics, 125, 1301-1307. https://doi.org/10.1542/peds.2009-0774

[24] Meyer, S.B. and Barbosa, D.R. (2007) Repeated Measures in Case Studies Relating Social Competence and Weight Loss in Two Obese Adolescents. International Journal of Behavioral Consultation and Therapy, 3, 384-393. https://doi.org/10.1037/h0100813

[25] Tsukayama, E., Toomey, S.L., Faith, M.S. and Duckworth, A.L. (2010) Self-Control as a Protective Factor against Overweight Status in the Transition from Childhood to Adolescence. Archives Pediatrics Adolescents Medecine, 164, 631-635. https://doi.org/10.1001/archpediatrics.2010.97

[26] de Niet, J., Timman, R., Jongejan, M., Passchier, J. and van den Akker, E. (2011) Predictors of Participant Dropout at Various Stages of a Pediatric Lifestyle Program. Pediatrics, 127, 164-170. https://doi.org/10.1542/peds.2010-0272

[27] de Niet, J., Timman, R., Rokx, C., Jongejan, M., Passchier, J. and van Den Akker, E. (2011) Somatic Complaints and Social Competence Predict Success in Childhood Overweight Treatment. International Journal of Pediatric Obesity, 6, 472-479. https://doi.org/10.3109/17477166.2011.575145

[28] Jackson, L.A., von Eye, A., Fitzgerald, H.E., Witt, E.A. and Zhao, Y. (2011) Internet Use, Videogame Playing and Cell Phone Use as Predictors of Children's Body Mass Index (BMI), Body Weight, Academic Performance, and Social and Overall Self-Esteem. Computers in Human Behavior Archive, 27, 599-604. https://doi.org/10.1016/j.chb.2010.10.019

[29] Jacobson, D. and Melnyk, B.M. (2011) Psychosocial Correlates of Healthy Beliefs, Choices, and Behaviors in Overweight and Obese School-Age Children: A Primary Care Healthy Choices Intervention Pilot Study. Journal of Pediatric Nursery, 26, 456-464. https://doi.org/10.1016/j.pedn.2011.07.001

[30] Rehkopf, D.H., Laraia, B.A., Segal, M., Braithwaite, D. and Epel, E. (2011) The Relative Importance of Predictors of Body Mass Index Change, Overweight and Obesity in Adolescent Girls. International Journal of Pediatric Obesity, 6, 233-242. https://doi.org/10.3109/17477166.2010.545410

[31] Vos, R.C., Wit, J.M., Pijl, H., Kruyff, C.C. and Houdijk, E.C.A.M. (2011) The Effect of family-Based Multidisciplinary Cognitive Behavioral Treatment in Children with Obesity: Study Protocol for a Randomized Controlled Trial. Trials, 12, 110. https://doi.org/10.1186/1745-6215-12-110

[32] Walpole, B., Dettmer, E., Morrongiello, B., McCrindle, B. and Hamilton, J. (2011) Motivational Interviewing as an Intervention to Increase Adolescent Self-Efficacy and Promote Weight Loss: Methodology and Design. BMC Public Health, 11, 459(2-9).

[33] Gunnarsdottir, T., Njardvik, U., Olafsdottir, A.S., Craighead, L. and Bjarnason, R. (2012) Childhood Obesity and Co-Morbid Problems: Effects of Epstein's Family-Based Behavioural Treatment in an Icelandic Sample. Journal of Evaluation in Clinical Practice, 18, 465-472. https://doi.org/10.1111/j.1365-2753.2010.01603.x

[34] Jacobson, D. and Melnyk, B.M. (2012) A Primary Care Healthy Choices Intervention Program for Overweight and Obese School-Age Children and Their Parents. Journal of Pediatric Health Care, 26, 126-138. https://doi.org/10.1016/j.pedhc.2010.07.004

[35] Walpole, B., Dettmer, E., Morrongiello, B.A., McCrindle, B.W. and Hamilton, J. (2013) Motivational Interviewing to Enhance Self-Efficacy and Promote Weight 
Loss in Overweight and Obese Adolescents: A Randomized Controlled Trial. Journal of Pediatric Psychology, 38, 944-953. https://doi.org/10.1093/jpepsy/jst023

[36] Powell-Young, Y.M., Zabaleta, J., Velasco-Gonzalez, C. and Sothern, M.S. (2013)A Cohort Study Evaluating the Implications of Biology, Weight Status and Socioeconomic Level on Global Self-Esteem Competence among Female African-American Adolescents. Journal of the National Black Nurses Association, 24, 1-8.

[37] Kulik, N.L., Fisher, E.B., Ward, D.S., Ennett, S.T., Bowling, J.M. and Tate, D.F. (2014) Peer Support Enhanced Social Support in Adolescent Females during Weight loss. American Journal of Health Behavior, 38, 789-800. https://doi.org/10.5993/AJHB.38.5.16

[38] Kulik, N., Ennett, S.T., Ward, D.S., Bowling, J.M., Fisher, E.B. and Tate, D.F. (2015) Brief Report: A Randomized Controlled Trial Examining Peer Support and Behavioral Weight Loss Treatment. Journal of Adolescence, 44, 117-123. https://doi.org/10.1016/j.adolescence.2015.07.010

[39] WHO, World Health Organization (2008) 10 Facts on Adolescent Health. http://www.who.int/features/factfiles/adolescent_health/en/index.html

[40] Jackson, S.L. and Cunningham, S.A. (2015) Social Competence and Obesity in Elementary School. American Journal of Public Health, 105, 153-158.

https://doi.org/10.2105/AJPH.2014.302208 